\section{Tris(2,3-dibromopropyl) Phosphate}

\section{CAS No. 126-72-7}

Reasonably anticipated to be a human carcinogen

First listed in the Second Annual Report on Carcinogens (1981)

Also known as TRIS

$$
\mathrm{Br}-\mathrm{CH}^{\mathrm{C}}
$$

\section{Carcinogenicity}

Tris(2,3-dibromopropyl) phosphate is reasonably anticipated to be a human carcinogen based on sufficient evidence of carcinogenicity from studies in experimental animals.

\section{Cancer Studies in Experimental Animals}

Tris(2,3-dibromopropyl) phosphate caused tumors in two rodent species, at several different tissue sites, and by two different routes of administration. Dietary administration of tris(2,3-dibromopropyl) phosphate caused benign or malignant tumors of the forestomach (squamous-cell papilloma or carcinoma) and lung (bronchiolar/ alveolar adenoma or carcinoma) in mice of both sexes; the kidney (tubular-cell adenoma or adenocarcinoma) in male mice and in rats of both sexes; and the liver (hepatocellular adenoma or carcinoma) in female mice (NCI 1978). Dermal exposure to tris(2,3-dibromopropyl) phosphate caused tumors of the skin, forestomach, lung, and oral cavity in female mice (IARC 1979).

Since tris(2,3-dibromopropyl) phosphate was listed in the Second Annual Report on Carcinogens, an additional study in rodents has been identified. In a study of limited duration, administration of tris(2,3-dibromopropyl) phosphate by stomach tube caused benign colon tumors in male rats (IARC 1987, 1999).

\section{Cancer Studies in Humans}

The data available from epidemiological studies are inadequate to evaluate the relationship between human cancer and exposure specifically to tris(2,3-dibromopropyl) phosphate.

\section{Properties}

Tris(2,3-dibromopropyl) phosphate is a haloalkyl phosphate that is a pale-yellow viscous liquid at room temperature. It is practically insoluble in water but is miscible with carbon tetrachloride, chloroform, and methylene chloride. It is stable in sunlight or at temperatures up to $200^{\circ} \mathrm{C}$ but is hydrolyzed by acids and bases (Akron 2009, IARC 1979). Physical and chemical properties of tris(2,3-dibromopropyl) phosphate are listed in the following table.

\begin{tabular}{ll} 
Property & Information \\
\hline Molecular weight & $697.6^{\mathrm{a}}$ \\
Specific gravity & 2.27 at $25^{\circ} \mathrm{C}^{\mathrm{a}}$ \\
Freezing point & $5.5^{\circ} \mathrm{C}^{\mathrm{a}}$ \\
Boiling point & $390^{\circ} \mathrm{C}^{\mathrm{b}}$ \\
Log $K_{\text {ow }}$ & $4.29^{\mathrm{a}}$ \\
Water solubility & $8 \mathrm{mg} / \mathrm{L}$ at $24^{\circ} \mathrm{C}^{\mathrm{a}}$ \\
Vapor pressure & $2.25 \times 10^{-4} \mathrm{~mm} \mathrm{Hg}$ at $25^{\circ} \mathrm{C}^{\mathrm{a}}$ \\
\hline
\end{tabular}

Sources: aHSDB 2009, ㄴIARC 1999.

\section{Use}

Tris(2,3-dibromopropyl) phosphate was used in the United States for making flame-retardant children's clothing (IPCS 1995). In 1977, the Consumer Product Safety Commission banned the use of tris(2,3-dibromopropyl) phosphate in children's clothing and in fabric, yarn, and fiber when intended for use in such clothing (CPSC 1977). Tris(2,3-dibromopropyl) phosphate has also been used as a flame retardant in polyurethane foams for cushioning, insulation, furniture, and automobile and aircraft interior parts, as well as in polystyrene foam, acrylic carpets and sheets, water flotation devices, polyvinyl and phenolic resins, paints, lacquers, paper coatings, styrene-butadiene rubber, and latexes (IARC 1979, 1999).

\section{Production}

Tris(2,3-dibromopropyl) phosphate was first produced in 1950 (IPCS 1995), and commercial production in the United States was first reported in 1959 (IARC 1979, 1999). In 1975, U.S. production was estimated at between 4.1 million and 5.4 million kilograms (9 million and 12 million pounds) (IARC 1979, IPCS 1995, HSDB 2009). In 2009, no commercial manufacturers of tris(2,3-dibromopropyl) phosphate were identified, but it was available from six U.S. suppliers (ChemSources 2009). No data on U.S. imports or exports of tris(2,3dibromopropyl) phosphate were found.

\section{Exposure}

The routes of potential human exposure to tris(2,3-dibromopropyl) phosphate are inhalation, dermal contact, and ingestion (NCI 1978). Because tris(2,3-dibromopropyl) phosphate is no longer reported to be produced in the United States, the potential for exposure should be small. The chemical was widely used in children's sleepwear and mattresses in the past. Exposure and environmental release could have occurred during the manufacture of flame-retardant material or leaching during use or washing. The treated garments could contain $5 \%$ to $10 \%$ tris(2,3-dibromopropyl) phosphate by weight (NCI 1978, IPCS 1995). The tris(2,3-dibromopropyl) phosphate metabolite 2,3-dibromo-1-propanol was found at concentrations of up to $29 \mathrm{ng} / \mathrm{mL}$ in the urine of children wearing treated polyester pajamas, and dermal absorption of tris(2,3-dibromopropyl) phosphate was estimated at $9 \mu \mathrm{g} / \mathrm{kg}$ of body weight per day (IARC 1979).

Tris(2,3-dibromopropyl) phosphate does not occur naturally, but it has been detected in food and water. The U.S. Environmental Protection Agency estimated in 1976 that as much as 10\% of U.S. tris(2,3dibromopropyl) phosphate production entered the environment from textile finishing plants and laundries and that the remainder was disposed of as solid waste (IARC 1979). EPA's Toxics Release Inventory reported environmental releases of tris(2,3-dibromopropyl) phosphate increasing from none in 1998 to $10 \mathrm{lb}$ in 2000 and $260 \mathrm{lb}$ in 2001. In 2002 and 2003, slightly over $300 \mathrm{lb}$ of tris(2,3-dibromopropyl) phosphate was released by one facility, including $250 \mathrm{lb}$ to surface water and nearly $60 \mathrm{lb}$ to air. In 2005, 2006, and 2007, $250 \mathrm{lb}$ was released to air and $10 \mathrm{lb}$ to an off-site hazardous-waste landfill (TRI 2009).

When released to air, tris(2,3-dibromopropyl) phosphate is expected to exist in the vapor phase and to react with photochemically produced hydroxyl radicals, with a half-life of about 14 hours at $25^{\circ} \mathrm{C}$. When released to surface water, it is expected to volatilize, with a half-life of 4 days in a model river and 38 days in a lake. Under basic conditions, it may hydrolyze in surface water; however, this is not expected to be a significant environmental fate process. It is not expected to bioaccumulate in aquatic organisms. When released to soil, tris(2,3-dibromopropyl) phosphate is expected to bind strongly to soil and sediment and to leach very slowly into groundwater. Tris(2,3-dibromopropyl) phosphate was detected at concen- 
trations ranging from 44 to $85 \mathrm{ng} / \mathrm{m}^{3}$ in five air samples collected in 1976 and 1977 at two industrial facilities synthesizing organobromine compounds. In 1979, it was detected, but not quantified, in air and soil in the state of Arkansas (HSDB 2009).

The National Occupational Hazard Survey (conducted from 1972 to 1974 ) estimated that 29,000 workers, primarily in the Telephone Communication industry, potentially were exposed to tris(2,3dibromopropyl) phosphate (NIOSH 1976).

\section{Regulations}

\section{Department of Transportation (DOT)}

Tris(2,3-dibromopropyl) phosphate is considered a hazardous substance, and special requirements have been set for transporting it in tank cars.

Environmental Protection Agency (EPA)

Comprehensive Environmental Response, Compensation, and Liability Act

Reportable quantity (RQ) $=10 \mathrm{lb}$.

Emergency Planning and Community Right-To-Know Act

Toxics Release Inventory: Listed substance subject to reporting requirements.

Resource Conservation and Recovery Act

Listed Hazardous Waste: Waste code for which the listing is based wholly or partly on the presence of tris(2,3-dibromopropyl) phosphate $=$ U235.

Listed as a hazardous constituent of waste.

\section{References}

Akron. 2009. The Chemical Database. The Department of Chemistry at the University of Akron. http://ull. chemistry.uakron.edu/erd and search on CAS number. Last accessed: 7/9/09.

ChemSources. 2009. Chem Sources - Chemical Search. Chemical Sources International. http://www. chemsources.com/chemonline.html and search on tris dibromopropyl phosphate. Last accessed: 7/9/09. CPSC. 1977. CPSC bans TRIS-treated children's garments. News from CPSC. U.S. Consumer Product Safety Commission. http://www.cpsc.gov/cpscpub/prerel/prhtml77/77030.html.

HSDB. 2009. Hazardous Substances Data Bank. National Library of Medicine. http://toxnet.nlm.nih.gov/ cgi-bin/sis/htmlgen?HSDB and search on CAS number. Last accessed: 7/9/09.

IARC. 1979. Tris(2,3-dibromopropyl) phosphate. In Some Halogenated Hydrocarbons. IARC Monographs on the Evaluation of Carcinogenic Risk of Chemicals to Humans, vol. 20. Lyon, France: International Agency for Research on Cancer. pp. 575-588.

IARC. 1987. Tris(2,3-dibromopropyl) phosphate. In Overall Evaluations of Carcinogenicity. IARC Monographs on the Evaluation of Carcinogenic Risk of Chemicals to Humans, suppl. 7. Lyon, France: International Agency for Research on Cancer. pp. 369-370.

IARC. 1999. Tris(2,3-dibromopropyl) phosphate. In Re-evaluation of Some Organic Chemicals, Hydrazine, and Hydrogen Peroxide. IARC Monographs on the Evaluation of Carcinogenic Risk of Chemicals to Humans, vol. 71. Lyon, France: International Agency for Research on Cancer. pp. 905-921.

IPCS. 1995. Environmental Health Criteria 173. Tris(2,3-dibromopropyl) Phosphate and Bis(2,3-dibromopropyl) Phosphate. International Programme on Chemical Safety. http://www.inchem.org/documents/ ehc/ehc/ehc173.htm.

NCI. 1978. Bioassay of Tris (2,3-dibromopropyl) Phosphate for Possible Carcinogenicity. NCI Technical Report Series no. 76. DHEW Publication No. (NIH) 78-1326. Bethesda, MD: National Cancer Institute. 117 pp.

NIOSH. 1976. National Occupational Hazard Survey (1972-74). DHEW (NIOSH) Publication No. 78-114. Cincinnati, $\mathrm{OH}$ : National Institute for Occupational Safety and Health.

TRI. 2009. TRI Explorer Chemical Report. U.S. Environmental Protection Agency. http://www.epa.gov/ triexplorer and select Tris(2,3-dibromopropyl) Phosphate. Last accessed: 7/9/09. 